\title{
ABRAHAM AND JESUS AS ANCIENT MIGRANTS: AN AFRICAN MIGRATION PERSPECTIVE
}

\author{
ZORODZAI DUBE*
}

University of Pretoria

\begin{abstract}
The study is a response to the call for papers that focuses on African issues and, I chose to discuss the issue of migration. Though not a historical document, the Bible records various journeys that the ancient people travelled; ${ }^{1}$ it narrates people's relocations from one geographic place to the other. However, migration has never been the main focus of several biblical interpreters who seem to perceive the Bible mostly from a theological lens. Largely, this study is informed by current challenges associated with immigration, highlighting comparative migration experiences that seem embellished under theological themes. For examples, each day we hear about stories of migrants who drown in the sea while trying to cross to Europe or of foreigners, due to xenophobic conflicts over few economic resources, die in numbers in South Africa. This study explores two biblical characters-Abraham and Jesus from a migration perspective, focusing on the pushed or pulled factors embedded under their stories.
\end{abstract}

KEY WORDS: Migration, Bible, Zimbabwe, Abraham, Jesus

\section{Introduction}

In comparison to previous generation that had no similar transport means, our generation travel longer journeys and it would not be an exaggeration to characterize ours as migration generation. As people migrate, social and economic challenges arise and concerning this, I began ruminating about what the Bible says about migration with a view to highlight comparative aspects to our own times. This led to the question-is migration only a contemporary problem-one which is foreign to the biblical world? Answering this question takes different directions. The first direction is to deny, based on time and geography, any link between the present problems associated with migration and the ancient society. This study takes the second option, which is to note comparative aspects between biblical passages that talks about migration and our context, thus allowing the two contexts to dia-

* ZORODZAI DUBE (PhD 2011, University of Oslo), is lecturer in contextual theology at the University of Pretoria. Email: zorodube@yahoo.com.

1 Though historical clues can be gleaned from the Bible, it is not primarily a historical book, rather narratives that contain how people related to God. 
logue. This may provoke the question-why force the Bible to talk about contemporary issues which, possibly, were not in existence then? The Bible has been used as platform to start discussion about many issues, including migration. For example, during the recent xenophobic attacks in South Africa, people used the Bible to respond against the attacks. Leviticus (19:3334) was posted on social media, to which various people responded 'amen' or 'yes'. The Old Testament text Leviticus 19 verses 33 to 34 says, 'when a stranger resides with you in your land, you shall not do him wrong. The stranger who resides with you shall be to you as the native among you, and you shall love him as yourself, for you were aliens in the land of Egypt; I am the LORD your God.' Besides such instances, migration perspective has never been consistently applied in reading particular biblical texts. Yet, with regards to migration and the bible, people travelled across geographic boundaries, which make the Bible a good discussion partner to migration issues. Therefore the following study is premised on the conviction that migration existed during the Biblical times, though we can differ concerning the extent to which the ancient people emigrate. Migration has always been a problem and, therefore to side-line migration while talking about people whether during the past or present is to minimize the evident truth that humans migrate from the time the Anthropos discovered the upright posture.

Today, due to great improvement in the means of travel, people travel far distances, compared to the ancient times where donkeys and carts were the means of transport. Today, as people emigrate from their traditional places linked with their ethnicity to other places, problems arise over fighting for the few resources and conflict in cultural complexity. Today, many people of Asians descent exist in large numbers in Africa, while a large number of African have migrated to Europe. This phenomenon has accentuated cultural complexity and, sometimes, xenophobia.

\section{Migration Challenges Today}

Within Social Sciences, migration issues are studied mainly by looking into the push or the pull factors. For example the pull factors are, skills labor migration and better working or living conditions (Gaidzanwa 1999:47). Mostly people from poor countries tend to migrates to rich countries in search of better living conditions, in the process, the rich countries are accused of indirectly under-developing the poor countries by snatching away their best talent (Gaidzanwa 1999:47). Push factors are when people migrate due to wars, violence, poverty and diseases. This is mostly characteristic of unskilled laborers who leave their countries of origin due to poor governance and civil wars (Peberdy and Crush 1998:5). There are several reports of unskilled people who migrate from West Africa to Europe, risking death at 
sea, while running away from poverty and wars in their home countries. Reports indicate that in 2014, 750 migrants died while trying to cross the 350 miles from Libyan coast to Lampedusa in Italy. 70000 are believed to have successfully sailed to Italy, which gives hope to more than 600000 who are believed to be waiting for their chance to cross the dreadful sea. ${ }^{2}$

There is reluctance and mixed feeling in Europe towards such unannounced visitors. Mostly, host countries legislate tougher rules which make it difficult for migrants to enter. There is a general perception that migrants are a burden to host countries. Previously, due to the unceasing wars in Somalia and Afghanistan, the Norwegian ${ }^{3}$ government willingly adopted thousands of refugees, especially women and children and supported them with monthly grants (Knudsen 2009:223). However, most of those refugees were unskilled labor, who perpetually survive on government aid and, sometimes, loiter along the streets, train stations and recreational parks, begging for food and money-thus becoming a social burden. This negative view towards migrants is mostly prevalent in countries with a large proportion of migrants, such as, Italy, Germany and Sweden. As an onlooker, Britain seem reluctant to take unskilled and burdensome excess population in under her care, which gives political parties such as the UK Independent Party (UKIP), political narratives that fan anti-immigration. ${ }^{4}$

Consequently, reports of overt and subtle racism aimed at excluding immigrates are being reported (Sträth 2008:21), with foreigners being excluded from workplaces, based on their skin color and origin. Clandestine excuses such as 'not speaking our language', 'not very skilled', 'not fitting our culture', are deployed to build an exclusive western identity. Despites their good educational training from their home countries, immigrants are confined to menial jobs such as distributing the daily newspapers and cleaning in hotels and restaurants. These menial jobs are avoided by the locals, which further inscribe an indelible mark of the 'other', 'the outsiders' or the foreigner. In addition to hostile local media that negatively label immigrants as unwanted objects, strict anti-migration laws contribute to xenophobia (Jones 2008:38). Some immigrants go to the extent of in learning latimes.com/world/europe/la-fg-italy-migrants-20140725-story.html\#page $=1$. Accessed 30 July 2014. ate student at University of Oslo, which give me some insights into the challenges of migration in Europe and Norway in particular.

The UK Independence Party is a Eurosceptic and right-wing populist political party in the United Kingdom. It was founded in 1993 by members of the Anti-Federalist League with the primary objective of securing the United Kingdom's withdrawal from the European Union. The party describes itself as a 'democratic, libertarian party'. 
the local languages and culture to fit into the host country, however, all the effect only allows them to lend jobs as cleaners in restaurants and hotels (Jones 2008:38). Ruth Wodak (2008:54) adds that each day, foreigners face the challenge of crossing the invisible erected binaries of 'us vis-à-vis them', 'insider vis-à-vis outsider', 'black vis-à-vis white'.

\section{Migration in the Bible}

Was the ancient world immune to our challenges of migration? That a majority of biblical scholars say little concerning migration further exacerbated the problem. Yet a closer look into the Bible vindicates the claim that the Bible chronicles people's journeys. I noted two factors that may hindrances the use of a migration perspective:

First, the Bible is cast as a sacred text; the inspired word of God which is only intended for spirituality and morality. This approach makes the reader to assume that the Bible is only a spiritual text that prepares us to meet with God-thus, highlighting only the theological theme within text and less about the social issues that the people faced.

Second, there is a tendency among critical readers to spiritualize the journeys within the Bible by reading biblical characters from the rubric of whether they obeyed God or not. For example, a majority of commentaries would read the story of the prophet Jonah and that of Abraham, emphasizing the moral and theological perspective.

Beside these hindrances, the historical critical approach, with its subsidiaries (form, textual, redaction criticism) focuses on retrieving the textual meaning hidden behind the text, which blinds the reader's attention from the social issues reflected by the stories (Segovia 1998:118). Historical critical method trains the readers to extract the meaning and, less about reconstructing the social events, thus, the approach is accused of being imperialistic, masculine and hegemonic; it silences and cuts-off the experiences of the readers from interacting with the text-thus accused of being a western tool that silences none-western readers (Segovia 1998:118). Equally, the theological approaches essentializes the aspect of obedience and faith; it fails to see that faith is not acted-out in vacuum.

\section{Abraham the Patriarchy or the Migrant}

Using migration perspective, I intent to highlight the pull and push factors within the story of Abraham and Jesus. Abraham is commonly dubbed as the patriarchy and not the migrant. Failure to read Abraham from a migration lens, shows the handicap or limitation of theories or perspectives that limits the types of questions we raise. Mostly, within theological and Bible college settings, the story of Abraham is regarded as a story of faith and obedience to God's calling, evoked to teach about obedience to God's calling 
and how to faithfully listen to God's voice, despite all odds. For example, in Abraham and the life of Faith, the author exhorts the readers saying, "like Abraham, the followers of Christ must leave their comfort zones and their riches in obedience to God's calling'. ${ }^{5}$ Noticeably, the focus is on obedience and faith. Even the New Testament narratives, such Romans and Hebrews, focus on Abraham as progenitor of faith.

Further, philosophers such as Søren Kierkegaard (2005:18) discusses Abraham from the perspective of ethics and faith. Kierkegaard thinks that the story of Abraham illustrates the hierarchy of social norms, in that, by leaving his family and willingness to kill his only son, Abraham obeyed the ontological or higher command. In doing this, Kierkegaard could not read the story of Abraham from the perspective of immigration.

Arguably, the story of Abraham is analogical to the experiences of the immigrants. Like an immigrant, Abraham was primarily a nomad (Albright 1935:11), meaning that he migrated from one geographic location to the other in search of pasture and food. Food and sustenance are the primary questions to migrants-these might be seen as pull or push factors. Among the Shona people of Zimbabwe, they have a saying that goes, 'Huswa hweNyati ndehuri mudumbu, huripamuromo, inofa nahwo', meaning to a buffalo, the grass that is inside its stomach is indeed his, but that which is still in the month, it might die before swallowing. The saying shows the slim distance between food and death-food is precarious and, looking for it, might lead to death. As nomad, Abraham left his home place to take up a diaspora status in Palestine (Habel 1995:116-117), migrating from Mesopotamia and settled in Canaan. The process of leaving one's locale to reside in another region, from the perspective of migration, cannot be considered a leap of faith. Instead, peasants and nomads survive as a group, if one leaves the group, there are high chance of death through raids from other nomads or wild animals. In addition, leaving one's clan diminishes the strength of the claim-its ability to protect and defend itself through numbers. This analogy from Abraham can be compared to migrants who risk death at sea and on land to cross to Europe. Migrants also leave their families in the process, exposing them to attacks by robbers and diseases. Research indicate that there is a correlation between migration and the spread of sexual transmitted diseases, especially, when partners spend time away from each other.

Along the way, Abraham stopped at various locations to recuperate and feed his livestock. Like other nomads, Abraham migrated because he was in search of better pasture for his livestock and food for his family. This aspect is comparable to contemporary migrants who travel from country to coun-

5 http://www.biblestudytools.com/commentaries/maclaren/genesis/abram-and-the-life.html, Abraham and the Story of Faith. Accessed 18 July 2014. 
try in search of a better place to settle. For example, in order to arrive at one's final destination, which is Europe, one passes through various countries for example Libya, where you pay illegal transporters to help cross the sea.

The story says that when Abraham settled in Canaan, he was an outsider or a foreigner, which is shown by buying land to bury his wife Sarah from Ephron, the Hittite, the son of Zohar (Genesis 23:2). Within the ancient societies, land was a sign of status; it was owned via one's ancestry, meaning that if your father owns land, and upon his death, the sons may share the same land. In addition it was common practice for the rich to buy land from the poor or displace them through violence, such as in the in the story of Ahab who killed and took Naboth's land (1 Kings 21:1ff). Today, the Maasai of Kenya, who are the pastoralists, may illustrate how land is a sign of status. Thus, as a pastoralist and yet without land, Abraham was a poor pastoralist. Analogically, a majority of foreigners who stay in Europe cannot afford the mortgages to own a house, a permanent job. Like Abraham, immigrants have no status and no rights.

Unlike the locals, migrants take time to settle in the country of their interest; approximately, a maximum of 10 years is needed for migrants to assimilate. If the whole household migrate, usually, the children or the second generation to the first migrants may assimilates better, after learning the language or education. From this perspective, the Abraham story may conceal a number of social issues, for instances how many years did Abraham took to settle in the land, what social and identity conflict did Abraham face from the locals? A glimpse to such challenges is given in Genesis 12, when the Abraham's shepherds quarreled with Lot's shepherds, a sign of internal conflict within the household. If such domestic disputes erupted, it is possible that similar quarrels over grazing land could have arose with other herdsmen in the region.

Importantly, migration includes women who are mostly the silent sufferers during the endless journeys. Pastoral cultures are patriarchal and they tend to silence the experiences of women, as is the case with Abraham's story. A study among the Maasai of Tanzania by the Swedish scholar Aud Talle (1990:73-93) indicates that women suffer the most during migration by carrying heavily load and by attending to children, while the men are involved in defending the valued livestock from wild animals and raiders. Naomi Kipuri (2006:246) adds that within nomadic groups, women are side-lined from political and economic roles and their role is confined to supporting men.

Concerning Abraham's story, the silencing of Sarah is clear and, feminist biblical scholars raise concerns regarding the scanty reference to Sarah within the narratives. Clearly, the entire narrative privileges Abraham at the 
expense of Sarah who is merely portrayed as the follower of her husband's nomadic decisions (Mckinlay 2003:140). The portrayal of women as followers, while men are construed as leaders and decision makers fits the discourses within ancient masculinities-where woman were seen as appendages to men's projects.

Today, due to migration, women suffer under the burden of looking after the children when their husbands travel abroad in search of better jobs. Only at a later stage when settled, do men begin to apply for visas for the wife and children to come. Sometimes, due to the strict visa policies or in the event that the man marries another woman, the wife and children may live without the father forever. In addition, during the period of separation while in the foreign land, men are vulnerable to sexual transmitted diseases and later infect their wives. Among patriarchal societies in Zimbabwe, only men are expected to travel, which further instils the prejudice that men are adventurous and fearless while women cannot venture outside without the protection of a man. The discourse to keep women at home while men travel abroad, entrenches the belief that a man can have sex with multiple partners while a women needs to be protected. A woman who travels without the company of a man is stereotyped as a sex-worker or is venerable to rape. A majority of men who cross the border to South Africa are without their families after leaving them back home with the extended family members. The absence of Sarah in most scenes, shows that the Abraham story was patriarchal-it silences the social and economic experiences of women.

\section{Jesus the Fugitive. Mark's Version}

Further, I illustrate how migration perspective works using the story of Jesus. Similar to Abraham, the story of Jesus has received much attention as a faith story that compels people to repentance and to await for the imminent parousia. Was Jesus a nomadic person or that he had a home? Jesus' parents were peasants, hence, why would a peasant like Jesus move about? John Panther (2009:249), on the basis on Mark 3 verse 21, suggests that Jesus had a house in Capernaum while his parents resided in Nazareth. Archaeological studies reveal that Capernaum was a village close to the Sea of Galilee and, probably from this site, Jesus witnessed the exploitation of labor by the rich and the struggles of the poor (Reed 2002:165). Jonathan Reed argues that Jesus lived during the time of growing feudalism, when the rich annexed land from the poor, leaving the poor with no option but to look for work or fend for themselves through fishing (Hanson and Douglas 1998:106). Richard Horsley (2001:38) suggests that the situation of being landless and being oppressed by the feudal lords, shaped Jesus' view of God as the protector of the oppressed and Jesus' call for the radical revamp of the asymmetric economic system. 
Peasants who survive on subsistence do not migrate, unless faced with push factors that force them to relocate. Migration studies reveal that people who mostly migrate are urban people who rent, compared to rural peasants who define their identity from their land. Taking the example of Zimbabwe, if peasants migrate, it would be the young adults who go to nearby towns to look for jobs, yet still maintain their links with their villages. The bottom line is that the peasants do not abandon their land.

Why then, did Jesus leave his family to start an itinerate lifestyle? Jesus characterized himself as a fox without a hole and as having nowhere to lay his head (Theissen 1986:20). What were the push factors? Jonathan Reed (1999:87) and Douglas Edward (1992:62) suggest that the peasants lost land due to feudalism. The Roman Empire had a tendency of awarding land to the retired general in Palestine (Richard Horsley 2001:38, Ched Myers 1991:23). ${ }^{6}$ There was growing influence of the Empire, especially, regarding land annexation and the growing number of tenancy. This may be regarded as the push factor. In addition, the itinerary lifestyle of Jesus, in view of the fact that Joseph had other sons, the small piece of land which the family had was not enough for all the sons, which might have forced Jesus to move and to search for a living at the sea. From this perspective, the Jesus story is analogical to boys who leave their parents, after realizing that life based on agriculture is not adequate.

Jesus is associated with migrants by being constantly on the move, which may reflect the growing number of the displaced peasants. When Jesus moves, he was not alone, many people followed him. Concerning the disciples, theologians trumpeted the messiahship of Jesus. I argue taking the issue of land displacement as a push factor, that the people who followed Jesus were displaced from their land by the Roman elite. A peasant without land loses the right to subsist and the network of kinship to fall back on. As Sean Frayne explains, peasants who lost their land became tenants or day laborers, while some fended for themselves through alternative economies such as fisherman, potters, and carpenters. Why were the men not tilling their land, instead of following Jesus? What had happened to their land? Mark 3:21ff says a large crowd followed Jesus which makes the reader to wonder why peasants would follow an itinerate teacher and leaving their household chores.

Immigrants tend to find alternative economic means after losing faith in their central government. Today, a majority of people who migrate come from failed governments, such as Somalia, Eretria, Ethiopia, and Zimbabwe, and even though they are qualified teachers and nurses in their home counthe First century Palestine.

PERICHORESIS 14.1 (2016) 
tries, they end up taking any menial job to survive. Compared to Jesus, migrants today relocate due to violence and the extractive policies of their governments. In most African countries, violence is a default button used by the ruling party government to silence the people. Equally, during Jesus' time, the Roman government had an extraction policy, meaning that colonies exist for extraction of resources and for cheap labor. Hence in Palestine, grain and fruits were siphoned to Rome. In addition, locally, ancient cities which were parasitical were inhabited by Roman elites (Crossan 1991:192, Reed 1999:89, Horsley 2001:31, van Erk 2003:1).

Immigrants are known to be entrepreneurial and innovative. During Jesus time, the peasants found Jesus' message of commensality and sharing as alternative economic system to that of the empire. Equally, according to Rudo Gaidzanwa (1999:47) the collapse of central governments in most African states, makes the citizen to develop alternative systems of survival, such as migrating and starting small businesses where they sell tomatoes, vegetable, and oil. The products are sold within the village and sometimes the peasants introduce batter trade to survive. In Zimbabwe, because of the government's failure to provide work, the local people begin selling vegetables and other small items along the streets. The immigrants in South Africa and in Europe send money back to their home countries in support of their families. Mostly the money is send via Western Union or other means.

For fear of persecution, immigrants do not speak openly against their governments. Comparably, the question whether Jesus spoke openly regarding his identity as messiah or that he was mute and timid to speak about such issues is contested. Early Jesus researchers to this issues, such as William Wrede (1857-1901), suggest that the messianic secrecy motif was a diplomatic stance for fear of victimization. Instead, after his resurrection, his followers revealed Jesus' real intention (Schweitzer 1910:13). However, Herman Reimarus (1694-1768) whose thesis was later posthumously published by Lessing (1725-1781) suggests that Jesus openly announced his political ambitions as messiah and was killed in the process (Schweitzer 1910:13). If we consider Wrede's thesis, Jesus must have gauged the situation which made him to secretly conceal his true identity. Clearly at his trial, Jesus could not give explicit answers regarding his political identity. Analogically, migrants do not criticize their government for fear of reprisals; like Jesus, they speak their true minds in private. James Scott says oppressed prefer to reveal their true identity 'off-stage' by name calling and other clandestine strategies that are all intended to obviously undermine authority (Scott 1990:136).

Further, immigrants avoid political question for fear of repression from the political leaders. For example, the Zimbabwean immigrants in South Africa prefer to do their ordinary activities of buying and selling and avoid 
politically related questions. If asked about politics issues back home, a majority of Zimbabwean fear to be sold out. This attitude further explains the loss of trust in the central government; hence people prefer to fend for themselves than looking up to the government. Comparably, Jesus' veiled criticism of the political leaders reminds us of similar clandestine activities by immigrants who prefer to use modern channels such as the Facebook and other internet options to criticism their leaders. Oppressed people use coded language, songs, and graffiti to camouflage their discontent.

Like an immigrants, Jesus only gave veiled criticism of the Empire. The Markan narrator does not hide the fact that Jesus rivalries the Empire, saying, 'as he went ashore he saw a great throng, and he had compassion on them, because they were like sheep without a shepherd'. Assuming the role of a shepherd is taking a leadership role, a guardian, and a protector role (Horsley 2001:31). These are social and political roles that were known to belong to the Caesar; it was Caesar alone who protected and was the generous benefactor to the poor by freely distributing bread and offering gladiator entertainment to the ordinary people. How could Jesus see himself as a shepherd without usurping the role of the empire and its representatives? No sooner did Jesus described to the people as the sheep without a shepherd that, he started to feed them. By feeding the hungry population Jesus may provoked in people's mind the wilderness exodus memories and heightened their hope for political freedom. Importantly, by feeding the poor and the hungry Jesus was duplicating the roles of the Empire that saw itself as the protector of the people; he diverted their attention from the emperor to himself (Dube 2007:45). His actions certainly evoked the question from the empire-who is he to feed my people? Like the discussion on Abraham, the migration perspective allows us to peel-off the predominantly theological lens and to reveal social, economic, and political issues embedded under the Jesus stories.

\section{Conclusion}

Using migration perspective, study reconstructs the possible experiences behind two narratives-that of Abraham and Jesus. With regards to Abraham, his nomadic lifestyle and struggle for survival is comparable to migrants who travel from place to place in search of better and safe place to exist. Embedded within the Abraham story are themes such as fight and conflict over resources and, the struggles of women-issues which are also present among migrants today. Equally, the story of Jesus reveal a number of push and pull factors such as displacement and violence. We can also see how Jesus, like immigrants negotiated structures of power and hegemony through seeking alternative economic avenues and, by employing indirect critique of power. Importantly, migration perspective, sociologically, reveal 
a number of issues within the text which cannot be unsurfaced through other theories. To people who are facing violence and whose concern is daily survival, the migration perspective allows for a dialectical interaction between the world of the Bible and that of the reader.

\section{Bibliography}

Albright WF (1939) The Israelite Conquest of Canaan in the Light of Archaeology. Bulletin of the American Schools of Oriental Research 74:11-12.

Crossan D (1991) The Historical Jesus: Life of a Mediterranean Jewish Peasant. New York, NY: HarperCollins.

Dube Z (2007) Kingdom of God in Mark's Feeding Stories. Oslo: University of Oslo. http://hdl.handle.net/10852/32919.

Edwards DR, Eshel E (2004) Language and Writing in Early Roman Galilee: Social Location of a Potter's Abecedary from Khirbet Qana. In Edwards DR (ed) Religion and Society in Roman Palestine: Old and New Approaches. New York, NY: Routledge, pp. 49-55.

Foucault M (1997) Of Other Spaces Utopias and Heterotopias. In Leach N (ed) Rethinking Architecture: A Reader in Cultural Theory. New York, NY: Routledge, pp. 330-336.

Gaidzanwa R (1999) Voting with their Feet: Migrant Zimbabwean Nurses and Doctors in the Era of Structural Adjustment. Uppsala: Nordiska Africaininstitute.

Hanson KC, Oakman D (1998) Palestine in the Time of Jesus. Minneapolis, $\mathrm{MN}$ : Fortress Press.

Horsely R (2001) Hearing the Whole Story: A Political Plot in Mark's Gospel. Louisville, KY: Westminster John Knox Press.

IMF Staff (April 2000) Globalization: Threat or Opportunity? International Monetary Fund. Accessed 30 July 2014: http://www.imf.org/external/np/exr/ib/2000/041200.-htm\#III.

Kierkegaard S (2005) Fear and Trembling. London: Penguin Books.

Kipuri N (2006) Human Rights Violation and Indigenous People of Africa. In Kipuri N, Goduka IN (eds) Indigenous People's Wisdom and Power: Affirming Our Knowledge through Narratives. London: Ashgate, pp. 246-270.

Knudsen K (2009) Scandinavian Neighbors with Different Characters: Attitudes towards Immigrants and National Identity in Norway and Sweden. Acta Sociologica 40(3): 223-243.

Mckinlay J (2003) Who's/Whose Sarah? In Boer R, Conrad E (eds) Redirected Travel: Alternative Journeys and Places in Biblical Studies. New York, NY: T\&T Clark, pp. 131-144.

Myers C (1991) Binding the Strong Man: A Political Reading of Mark's Story of Jesus. Maryknoll, NY: Orbis Books. 
Peberdy S, Crush J (1998) Trading Places: Cross-border Traders and the South African Informal Economy. SAMP Migration Policy Series 6. Cape Town: Idasa/SAMP.

Reed J (1999) Galileans, Israelite Village Communities, and the Sayings Q. In Meyers E (ed) Galilee through the Centuries: Confluence of Cultures. Winona, IN: Eisenbrauns, pp. 89-108.

Reed J (2002) Archaeology and the Galilean Jesus: A Re-Examination of Evidence. Harrisburg, PA: Trinity International Press.

Sanders EP (1993) The Historical Figure of Jesus. London: Penguin Press.

Schweitzer A (1910) The Quest of the Historical Jesus: A Critical Study of Its Progress from Reimarus to Wrede. London: A\&C Black.

Scott J (1990) Domination and Arts of Resistance: Hidden Transcripts. New Haven, CT: Yale University Press.

Segovia FF (1998) Pedagogical Discourse and Practices in Cultural Studies: Towards a Contextual Biblical Pedagogy. In Segovia FF, Tolbert MA (eds) Teaching the Bible: The Discourse and Politics of Biblical Pedagogy. Maryknoll, NY: Orbis Books, pp.118-136.

Talle A (1990) Way of Milk and Meat among the Maasai. In Palsson G (ed) From Water to World Making: African Models and Arid Lands. Uppsala: Scandinavian Institute of African Studies, pp. 73-93.

Theissen G (1986) The Shadow of the Galilean. London: SCM Press.

Van Erk E (2003) Mission, Identity and Ethics in Mark: Jesus the Patron for Outsiders. HTS Teologiese Studies/Theological Studies 69(1): Art. \#2003, 13 pages. http://dx.doi.org/10.4102/hts.v69i1.2003.

Weber M (1946) From Marx Weber: Essays in Sociology. New York, NY: Oxford University Press.

Yamasaki G (1998) John the Baptist in Life and Death: Audience Criticism of Matthew's Narrative. Sheffield: Sheffield University Press.

\section{Online Material}

Abraham and the Story of Faith. http://www.biblestudytools.com/commentaries/maclaren/genesis/abram-and-the-life.html. Accessed 18 July 2014.

Italy Tries to Cope with Crush of Immigrants Seeking Refuge in Europe: http://www.latimes.com/world/europe/la-fg-italy-migrants-20140725-story.html\# page = 1 . Accessed 30 July 2014 . 